\title{
Türkiye'de Hoşnutsuzluk Endeksinin Seçmen Tercihleri Üzerindeki Etkileri: 1960-2019 Arası Bir İnceleme ${ }^{1}$
}

\author{
Emre DEMIR \\ Doktora Öğrencisi, Muğla Sttk1 Koçman Üniversitesi, \\ Sosyal Bilimler Enstitüsü, İktisat Ana Bilim Dalı \\ emredemir3407@gmail.com \\ Orcid ID: https://orcid.org/0000-0001-7881-9575
}

\author{
Ali ÇIMAT \\ Prof. Dr., Muğla Sttk1 Koçman Üniversitesi, \\ İktisadi ve İdari Bilimler Fakültesi, İktisat Bölümü \\ acimat@mu.edu.tr \\ Orcid ID: https://orcid.org/0000-0003-4423-4696
}

\begin{abstract}
Öz
Hoşnutsuzluk endeksi; enflasyon oranı ve işsizlik oranının toplamından türetilmektedir. Bu parametrede bir artış meydana gelmesi, insanların ekonomik koşullarının kötüye gittiğini ve dolayısıyla, gelecekteki beklentilerini kötüleştirdiğini işaret etmektedir. Çalışmanın amacı, Türkiye'deki seçmenlerin yöneticileri/iktidarları belirlerken enflasyon ve işsizlik oranlarından etkilendiğini veya etkilenmediğini belirlemektir. 1960 darbesi sonrası veriler hesaplanarak, Türkiye'de gerçekleșen genel seçim süreçlerinde seçmenlerin nasıl bir tercihte bulunduğu analiz edilmiştir. Diğer bir ifadeyle 1960-2019 yılları arasında enflasyon ve işsizlik verileri hesaplamaları ile sandık sonuçları incelenmiştir. Analiz sonucunda elde edilen bulgularda; seçmen davranışının Türkiye'de 1980 öncesi ve sonrası dönemde farklılık gösterdiği görülmüştür. 1980 öncesi Türk seçmeninin sandıkta daha çok ideolojik ve siyasi istikrar odağında davranışı görülürken; 1980 sonrasında bu durum tersine dönmüş ve ekonomik faktörlerin, diğer bir ifadeyle makroekonomik göstergelerin, seçmenlerin sandıktaki davranışı üzerinde etkilerinin daha ağır bastığ tespit edilmiştir.
\end{abstract}

\footnotetext{
${ }^{1}$ Makale Geliş/Kabul Tarihi: 05.12.2019 / 31.05.2021

Künye Bilgisi: Demir, E. ve Çımat, A. (2021). Türkiye'de hoşnutsuzluk endeksinin seçmen tercihleri üzerindeki etkileri: 1960-2019 arası bir inceleme. Kahramanmaraş Sütçü Imam Üniversitesi Sosyal Bilimler Dergisi, 18(2), 1167-1190. DOI: 10.33437/ksusbd.655458.
} 
Anahtar Kelimeler: Enflasyon, İşsizlik, Hoşnutsuzluk Endeksi, Seçmen Tercihleri, Türkiye Ekonomisi.

\section{The Impact of Misery Index on Voters Prefer in Turkey: An Analysis Between 1960-2019 \\ Abstract}

Misery index; it is derived from the sum of the inflation rate and the unemployment rate. An increase in this parameter (increase in unemployment and inflation rate) indicates that people's economic conditions are deteriorating and hence deteriorating their future expectations. The purpose of the study, the manager of the voters in Turkey are / were affected by the power of determining the inflation and unemployment rates to determine whether or not affected. After the 1960 coup, calculated data, while voters in the general election held in Turkey has been analyzed how the process made a choice. In other words, inflation and unemployment data calculations and polling results were examined between 1960-2019. In the results obtained from the analysis; In Turkey voter behavior has been observed that variations in the period before and after 1980. While the pre-1980 Turkish voters behaved more focused on ideological and political stability in the ballot box, this situation reversed after 1980 and it was found that the effects of economic factors on voter behavior were predominantly realized.

Keywords: Inflation, Unemployment, Misery Index, Voters Prefer, Case of Turkey.

\section{GİRIŞ}

Genel olarak bir ülkenin vatandaşlarının yaşam kalitesi; hepsinin makroekonomik performansla ilgili olduğu istihdam seviyesine, fiyat istikrarına ve ekonomik büyümeye bağlıdır. Ancak aynı birimlerdeki değişkenleri ifade etmedeki güçlükler, bu değişkenler arasındaki önem düzeyindeki değişkenlik derecesi ve değişkenlerin bazıları arasındaki mevcut bağlantılar gibi nedenlerle makroekonomik performansı değerlendirmek oldukça zordur (Moesen ve Cherchye, 1998). Bu bağlamda, ekonomilere olan doğrudan ve dolaylı olumlu veya olumsuz etkileri nedeniyle enflasyon ve işsizlik oranları hem politika yapıcılar hem de ekonomik birimler için büyük önem taşımaktadır.

Enflasyon, gelir dağılımının bozulmasına sebebiyet vererek sosyal ve politik sorunlara neden olmaktadır. İşsizlik ise vergi gelirlerini azaltan, gelir dağılımını bozan ve üretim kaybına sebep olan bir ekonomik göstergedir (Herman, 2010). Enflasyon, sektörler arasında kaynak tahsisini olumsuz yönde etkileyebilmekte ve ekonomik birimlerin yerel para birimlerine olan güvenini azaltmaktadır. 
İşsizliğin ise ekonomik maliyetleri dışında sosyal maliyetleri de önem arz etmektedir. Bunlar; sosyal statü kaybı ve suç oranlarının artmasıdır. $\mathrm{Bu}$ konjonktürde hem yüksek enflasyon hem de yüksek işsizlik rakamları daha yüksek ekonomik ve sosyal maliyetler içermektedir (Grabia, 2011).

Demokratik toplumlarda siyasal katılmanın bir aracı olarak kabul edilen seçimler, siyasal iletişimin yoğun olarak kullanıldığı bir alandır. Seçimler, halkın ihtiyaçlarını karşılayabilecek ve sorumluluk duygusuyla hesap verebilecek kadroları işbaşına getiren bir araç olarak kabul edilmektedir (Özkan, 2010: 214). $\mathrm{Bu}$ süreçte seçmenlerin seçim tercihlerini etkileyen belirli unsurlar bulunmaktadır. Bunlar; seçmenlerin maddi refahını etkileyen işsizlik, enflasyon gibi ekonomik göstergeler veya belli bir partiye, ideolojiye veya parti liderine olan bağ lılı̆̆ıdır. Ayrıca bu husus, Türkiye gibi gelişmekte olan ülkeler ile gelişmiş ülkeler arasında farkl11ıklar gösterebilmektedir.

Türkiye'de Cumhuriyetin ilanı ile birlikte gelişen siyasi süreç ve katılım olgusu; 1924 anayasası, çok partili hayata geçiş süreci, kadınlara seçme seçilme hakkının tanınması gibi birçok gelişmeler ile desteklenmiştir (Özer ve Meder, 2008: 1-2). Ancak 1960, 1971, 1980, 1998 yıllarında yaşanan darbe ve darbe girişimleri ile sivil siyaset üzerinde hakimiyet kuran askeri irade, birçok konuda seçmen davranışı üzerinde etkili olmuş, aynı zamanda sivil siyasette yaşanan kargaşalar beraberinde toplumsal kutuplaşmalara da sebebiyet vermiştir. Türkiye'de yaşanan bu gelişmeler dolayısıyla yönetimlerin ekonomik performansları da olumsuz etkilemiştir.

Çalışmanın amacı, Türkiye'de hoşnutsuzluk endeksinin seçmen tercihleri üzerindeki etkilerini ortaya koymaktır. Bu bağlamda Türkiye'de 1960 yılı itibari ile hoşnutsuzluk endeksi oranları hesaplanmış ve seçim sonuçları ile karşılaştırma yapılarak, bu endeksin seçmen tercihleri üzerindeki rolü incelenmiştir. Ayrıca çalışma, hükümetler arasındaki makroekonomik performansların karşılaştırılmasına imkân tanımaktadır.

Bu çalışmanın geri kalanı şu şekilde devam etmektedir: İkinci bölümde, hoşnutsuzluk endeksine ilişkin teorik yaklaşımlar yer almakta; üçüncü bölümde, 1960 yılından itibaren Türkiye'nin hoşnutsuzluk endeksleri ile seçim sonuçları karşılaştırılmakta; dördüncü ve son bölüm ise sonuçları ve tartı̧̧mayı sunmaktadir.

\section{HOŞNUTSUZLUK ENDEKSINNE İLIŞKINN TEORIK ÇERÇEVE}

İstikrarlı bir şekilde düşük enflasyonda yüksek ekonomik büyüme, dünya ekonomilerinin tercih ettiği ana hedeflerden biridir. Ancak ülke ekonomilerinin bu hedefleri doğrultusundaki ekonomik performanslarında bazı zorluklar ile karşılaşılmaktadır. Özellikle bir konu ile ilgili pek çok değişkenin varlı̆ğ, bu 
değişkenlerin belli bir ağılıklı ortalamasından oluşan endekslerin geliştirilmesini zorunlu kılmaktadır. Bu bağlamda, makroekonomik performansın ölçümüne yönelik geliştirilen ilk endeks, Okun (1970) tarafından geliştirilen İktisadi Hoşnutsuzluk Endeksidir. Bu endeks, işsizlik ve enflasyon oranının toplanmasından ibaret olup, endeksin değerinin yükselmesi daha kötü bir ekonomik performansı temsil etmektedir. Daha sonraki yıllarda Robert Barro (1999), Okun'un endeksini iyileştirerek, hükümetler arasında daha iyi makroekonomik performans karşılaştırmaları yapılmasını sağlamak amacıyla hoşnutsuzluk endeksine uzun dönem faiz oranları ve Gayri Safi Yurtiçi Hâsıla (GSYH)'nin uzun dönem ortalama değerinden sapmalarını ekleyerek dört değişkenli Barro Mutsuzluk Endeksini türetmiştir. Barro'nun endeksine göre enflasyon - işsizlik oranının ve tahvil faizlerinin artması, GSYİH'nin ortalama büyüme oranının altında kalması durumunda kötü makroekonomik performansı ve hoşnutsuzluğun arttığını göstermektedir. Barro'dan sonra da Okun'un endeksini yeniden yorumlayan Hanke (2018); işsizlik, enflasyon ve banka kredi faizi oranları toplamından kişi başına düşen GSYH'deki yıllık artış oranının çıkarılmasıyla oluşan bir mutsuzluk endeksi türetmiştir.

Lechman'a göre (2009) hoşnutsuzluk endeksi, fakirliğin kusursuz bir ölçütü olmamasına karşın, ekonomik performanstaki değişiklikleri yansıtmaktadır. Dolayısıyla, ekonominin iniş ve çıkışlarını yakalamak ve genel ekonomisinin performansını belirlemek amaciyla bu endeks kullanılabilmektedir. Welsch (2007), insanların bir yandan büyüme ve işsizliği, diğer yandan istikrarı önemsemediğini öne sürmektedir. Bu görüşe göre istikrar, alternatif olarak enflasyon oranı veya uzun vadeli faiz oranı ile sağlanmaktadır. Blanchflower'a (2007) göre ise işsizlik, mutluluğu enflasyondan daha çok azaltmaktadır. Eğitim seviyeleri düşük olan insanlar ve yaşlılar, işsizlikten ziyade enflasyondan endişe duyarken; genç ve eğitim seviyesi iyi olanlar için durum tam tersini göstermektedir.

\section{SEÇMEN DAVRANIŞINA İLIŞKİN TEORIKK ÇERÇEVE}

Seçmen; bir ülkenin vatandaşı sıfatınca birtakım hak ve görevlere sahip olan, ülkedeki yönetici kadrosunu belirleyen ve seçimlere katılan kişiler olarak tabir edilmektedir. Seçmen davranışı ise yurttaşların doğrudan veya dolaylı olarak yönetici kadroyu seçmek ve kamu politikasının şekillenmesinde etki etmek amacıyla katıldıkları ortak bir faaliyet alanıdır (Özer ve Meder, 2008: 30-31).

Batı demokrasilerinde seçmen davranışıyla alakalı birçok ampirik çalışma yapılmış hatta siyaset bilimcileri tarafından kuramlar ortaya atılmıştır. Türkiye'de ise bu çalışmaların çok geç başladığını görülmektedir. Bunun sebebi, Türkiye'de siyaset bilimcilerinin seçmen davranışı araştırmalarından önce meşruluk krizlerini, askeri darbeleri ve iç güvenlik sorunu olan terörü ele 
almalarıdır (Akgün, 2000: 76). Seçmen davranışı ile alakalı çalışmaların 1990'lı yıllardan sonra önem kazandığ 1 ifade edilebilir. Alanın son haline gelmesinde 1999 seçimlerinde gerek kamuoyu araştırma şirketleri tarafindan yapılan çalışmalar gerekse üniversitelerin seçmen davranışı üzerine yaptığı çalışmalar etkili olmuştur (Çakır ve Biçer, 2014: 99).

Literatürde seçmen davranışıyla ilgili ilk çalışmalar 1910'lı yıllarda başlamıştır. Akabinde, 1940'lardan itibaren özellikle Amerika'da (ABD) gelişerek devam etmiştir. 1940'lardan günümüze kadar gelen çalışmalarda üç temel yaklaşım ortaya atılmıştır. Bu yaklaşımları "sosyo-psikolojik", "rasyonel tercih" ve "sosyolojik yaklaşım" olarak sınıflandırmak mümkündür (Özer ve Meder, 2008: 32).

Partiyle özdeşleşme modeli olarak da adlandırılan sosyo-psikolojik yaklaşım; kişinin benimsediği partiyle arasında psikolojik bir bağlılığın olduğunu ifade etmektedir. Buna göre kişi, bir futbol takımı tutar gibi fanatik anlamda kendini bir partiye bağımlı hissetmekte ve kendini artık o partinin bir taraftarı kabul etmektedir. Bu yaklaşımın literatüre kazandırdığı en önemli kavram "parti kimliği”dir (Akgün, 2000: 78). Türkiye'de partiyle özdeşleşme modeline örnek olarak; yüksek eğitim düzeyine sahip, bürokratik ve aydın çevrelerin, küreselleşme sürecinin dayattığı değişim ve dönüşümden, dönemin getirdiği yaklaşımlardan etkilenmeden her şeye rağmen değişmeyen tek tercihlerinin kökleri derinlere dayanan "Cumhuriyet Halk Partisi" (CHP) kesimi; aynı şekilde kendisini ülkücü, milliyetçi olarak nitelendiren kesim, milliyetçiliğin temsili olarak gördükleri “Milliyetçi Hareket Partisi”ni (MHP) bu bağlılık duygusuyla desteklemektedirler (Gül vd., 2015: 228).

Rasyonel tercih modeli yaklaşımına göre seçmen oy kullanırken; partinin icraatlarını, hizmet akışını, politikalarını, ekonomik performansını ve parti liderlerini dikkate almaktadır. Seçmen, duyguları ile hareket etmek yerine aklıyla hareket ederek çıkarlarına göre tercih yapmaktadır (Özer ve Meder, 2008: 34). Türkiye'de Adnan Menderes döneminin seçmen davranışları, Rasyonel tercih modeline örnek olarak gösterilebilir.

Sosyolojik modele göre bireylerin sosyal özellikleri, sosyo-ekonomik statüsü, yaşadığı coğrafi mekânı, mensup olunan grubu vb. gibi faktörler parti tercihini etkilerken; kişisel tutum ve değer sistemleri oy verirken etkili değildir. Columbia Ekolü olarak da adlandırılan bu yaklaşım Columbia Üniversitesi'nde bir grup sosyal araştırmacı tarafından yapılan alan araştırmalarından edinilen bilgiye göre şekillenmiştir (Akgün, 2000: 77).

Seçmen; siyasal tercihte bulunmadan önce toplumda var olan ekonomik sorunların çözülmesini istemekte ve bu doğrultu da partilerin vaatlerini dikkate almaktadır. Türkiye'de seçmen; işsizlik, enflasyon ve ekonomik büyüme gibi 
göstergelere önem vermektedir (Çaha, 2008: 44). Bu hususta, milli gelirde gerçekleşen artışlar iktidarın oylarını pozitif yönde etkilerken; enflasyon ve işsizlik oranlarındaki artışlar iktidarın oylarını negatif yönde etkilemektedir (Ercins, 2007: 29).

Türkiye'de seçmen tercihine etki eden faktörlere ilişkin yapılmış olan araştırmalarda farklı sonuçlar tespit edilmiştir. Bu hususta bazı görüşler şu şekildedir: Kalaycıŏglu'na (1999) göre Türkiye'deki seçmen davranışı sosyoekonomik faktörlerden çok ideolojik ve kültürel faaliyetlere bağlıdır. Sencer (1974), Türkiye'deki seçmenlerin geleceği göz önünde bulundurmaktan ziyade geçmişteki ekonomik durumu dikkate aldığını öne sürmekte ve diğer kimi araştırmacılar gibi seçmen davranışını şekillendiren en önemli ve belirleyici faktörün ekonomik faktör olduğunun altını çizmektedir. Esmer (2002), 2002 yılında yaptığı analizine dayanarak, parti seçimindeki en önemli tanımlayıcı unsurun sol-sağ ideolojilerin olduğunu ileri sürmüştür.

\section{LITERATÜR TARAMASI}

İşsizlik ve enflasyon düzeylerinin toplamı olan hoşnutsuzluk endeksindeki hareket, bir topluluğun makroekonomik refah düzeyindeki hareketleri izlemek için kullanılmıştır. Hoşnutsuzluk endeksindeki azalan (veya artan) bir değerin refahı arttırması (veya azaltması) beklenmektedir. Bu çalışmada kullanılan endeks; Okun (1970) tarafindan geliştirilen İktisadi Hoşnutsuzluk Endeksidir. Diğer bir ifadeyle, işsizlik ve enflasyon değişkenlerinin toplamıyla elde edilen endeks değerleri ele alınmıştır.

Literatürde, konuya yakın çalışmalar bulunmaktadır. Başka bir anlamda, literatürde hoşnutsuzluk endeksinin iktidar onayı ve popülerliğine olan etkileri ile ilgili çalışmalar bulunmakta ve bu çalışmalar ilk olarak ABD'de görülmektedir. $\mathrm{Bu}$ çalışmalar için oldukça geç kalınmakla birlikte, ABD'deki çalışmalar ilk olarak 1970'lerde başlamaktadır. Bu bağlamda Mueller $(1970,1973)$ yapmış olduğu bir dizi regresyon analizi ile ekonominin durumu ve cumhurbaşkanlı̆̆ 1 seçimi arasında asimetrik bir ilişki olduğunu ortaya koymuştur. Yine durağan olmayan zaman serileri ile oluşturulan regresyon analizleri ile yaptıkları çalışmalarla Kenski (1977, 1980), Fair (1978, 1982, 1988), Rogoff ve Sibert (1988) aynı sonuç üzerinde yoğunlaşmışlardır.

Konu ile ilgili literatür, kesin sonuçlar olmamasına karşın ekonominin durumunun görevdeki başkanın popülaritesini etkilediğini kabul etme eğilimindedir. Durağan olmayan zaman serisi analizlerinde yaşanan hataların varlığı veya konu ile ilgili çok fazla çalışmanın olmayışı da bu sonuç ile örtüşmektedir. Bu hususta Norpoth (1984: 266), ekonomik performansın cumhurbaşkanlığı popülerliği için önemli olduğuna dair şüphenin olmayacağ 1 görüşünü sunmaktadır. Dickerson (2016) ise yapmış olduğu çalışmada ekonomik 
durgunluk dönemlerinin başkanlık onay oranı üzerinde güçlü olumsuz etkilere yol açabileceğini ortaya koymuştur. Ancak Choi vd. (2016), 1960 yilının ilk çeyreğinden 2012 yılının ikinci çeyreğine kadar üçer aylık veriler ile doğrusal olmayan bir eşik modelini tahmin ederek yeni bir yaklaşım ile yapmış oldukları çalışmada, diğerlerinin aksine, ekonomi ile cumhurbaşkanlığ 1 onayı arasındaki ilişkinin doğrusal olmadığını sonucuna varmışlardır. Konu ile ilgili en anlamlı çalışmalardan biri Adrangi ve Macri'ye (2019) aittir. Adrangi ve Macri (2019), Layton'un (1992) makroekonomik modelini probit ve logit regresyon analizini kullanarak yapmış oldukları çalışma sonucunda hoşnutsuzluk endeksi ile Cumhurbaşkanlığı seçimleri arasında anlamlı bir ilişki tespit etmişlerdir. Sonuçlarda, işsizlik oranındaki yüzde bir artışın, ABD Başkanı'nın olumlu onay notu alma olasılığını yüzde üç azaltmaktadır. Sunulan literatürden anlaşılacağ 1 üzere, ülkelerin ekonomik performansı bu açıdan seçimlerde önemli ölçüde etkin rol oynamaktadır.

Konu ile ilişkili Türkiye'de yapılmış olan bazı çalışmalarda mevcuttur. Çarkoğlu ve Toprak (2000) tarafından yapılan bir çalışma kapsamında yer alan anket sonuçları göre, geçmiş bir yıl içerisinde iktidardaki partinin uyguladığ 1 iktisat politikalarının gerek seçmen ailesinin ekonomik durumu gerekse makro ekonomik dengeler üzerinde yaptığı tahripkâr etkiler, iktidara yönelik desteğin azalmasına yol açmaktadır. Çinko'nun (2006) yapmış olduğu çalışma sonucunda, Türkiye'de hükümetlerin görev süreleri boyunca izlediği tutarsı, iktisadi koşullarla örtüşmeyen, makro-ekonomik politikalar seçmen tercihlerini olumsuz yönde etkilediğini tespit etmiştir. Adaman vd. (2001) tarafından yürütülen bir araştırma kapsamında yapılan anketten çıkan sonuçlara göre seçmenler, ağırlıklı olarak enflasyon ve işsizlik gibi iktisadi sorunların ilk olarak çözülmesini talep etmektedirler. Gerçekten de Türkiye açısından bakıldığında seçmenlerin, özellikle kriz dönemlerinde partileri büyük ölçüde cezalandırmaları, bu hususta eğilimin ağırlıklı olarak ekonomik yönlü olduğunun kanıtları sayılabilmektedir.

\section{TÜRKIYYE'DE HOŞNUTSUZLUK ENDEKSİ VE SEÇIMM SONUÇLARI}

Türkiye'de 1960-2019 yılları ele alınarak hazırlanan bu çalışma, üç bölüme ayrılmıştır. İlk bölümde 1960-1980 yılları arasındaki hoşnutsuzluk endeksi hesaplanmış ve bu yıllardaki seçim sonuçları ve seçime katılım oranları sunulmuştur. İkinci bölümde 1980-2002 yılları arasında hoşnutsuzluk endeksi hesaplanmış ve bu yıllardaki seçim sonuçları ve seçime katılım oranları gösterilmiştir. Üçüncü, yani son bölümde ise 2002 y1lı sonrasında hoşnutsuzluk endeksi ve seçim sonuçlarına ilişkin karşılaştırmalar yapılmıştır. Hesaplanan hoşnutsuzluk endeksi verileri ayrıca Ek-1'de sunulmuştur. Bu ayrımın temel sebepleri arasında Türkiye'nin ekonomi politikalar, siyasi süreçleri ve toplumsal gelişmeler yer almaktadır. Öyle ki 1980 öncesi ithal ikameci politika izleyen Türkiye ekonomisi; 24 Ocak 1980 sonrası serbest piyasa ekonomisine geçerek 
yeni bir döneme girmiş, ilaveten bu dönemde bir askeri darbe gerçekleşmiş ve birçok siyasi parti kapatılmış veya dağıtılmıştır. Yine 2001 yılında gerçekleşen kriz, 2002 seçimlerinde krize sebep olan koalisyon partilerinin meclise girememesiyle sonuçlanmıştır. Bu gelişmeler göz önüne alındığında yıllara göre ayrımların konu açısından gerekliliği ortaya çıkmaktadır.

\section{0 - 1980 Yılları Arasında Hoşnutsuzluk Endeksi ve Seçim Sonuçları}

Türkiye'de on yıllık Demokrat Parti iktidarını sona erdiren ve uzun yıllar askeri vesayetin sivil siyaset üzerinde baskı kurmasına neden olan 27 Mayıs 1960 darbesi ile askeri yönetim; parlamentoyu feshetmiş, anayasayı askıya almış, iktidardaki Demokrat Parti'yi kapatmış ve Cemal Gürsel Cumhurbaşkanı seçmiştir. Bu tarihten itibaren 1980 darbesine kadar sırasiyla 1961, 1965, 1969, 1973 ve 1977 yıllarında genel seçim yapılmıştır. Bu hususta Türkiye'de 1960 1980 yılları arasında gerçekleşen genel seçimlerde kullanılan, geçersiz sayılan oy miktarları ve seçime katılım oranları Tablo 1.'de gösterilmiştir.

Tablo 1. Türkiye'de Seçim Y1lları ve Oy Kapasiteleri “1960-1980”

\begin{tabular}{|l|l|c|l|l|l|l|}
\hline $\begin{array}{l}\text { Seçim } \\
\text { Yılı }\end{array}$ & $\begin{array}{l}\text { Seçim } \\
\text { Tarihi }\end{array}$ & $\begin{array}{l}\text { Millet } \\
\text { Vekili } \\
\text { Sayısı }\end{array}$ & $\begin{array}{l}\text { Kullanılan } \\
\text { Oy }\end{array}$ & $\begin{array}{l}\text { Geçerli } \\
\text { Oy }\end{array}$ & $\begin{array}{l}\text { Geçersiz } \\
\text { Oy }\end{array}$ & $\begin{array}{l}\text { Katılım } \\
\text { Oranı }\end{array}$ \\
\hline $\mathbf{1 9 6 1}$ & $15 / 10 / 1961$ & 450 & 10.522 .716 & 10.138 .035 & 384.681 & $\% 81,4$ \\
\hline $\mathbf{1 9 6 5}$ & $10 / 10 / 1965$ & 450 & 9.748 .678 & 9.307 .563 & 441.115 & $\% 71,3$ \\
\hline $\mathbf{1 9 6 9}$ & $12 / 10 / 1969$ & 450 & 9.516 .062 & 9.086 .381 & 429.681 & $\% 64,3$ \\
\hline $\mathbf{1 9 7 3}$ & $14 / 10 / 1973$ & 450 & 11.223 .843 & 10.723 .658 & 500.185 & $\% 66,8$ \\
\hline $\mathbf{1 9 7 7}$ & $05 / 06 / 1977$ & 450 & 15.368 .210 & 14.827 .172 & 541.038 & $\% 72,4$ \\
\hline
\end{tabular}

Kaynak: Türkiye Büyük Millet Meclisi Kütüphane ve Arşiv Hizmetleri Başkanlığı

Yukarıda gösterilen Tablo 1.'de ele alınan yıllar içerisindeki seçim dönemlerinde katılım oranlarının çok düşük olduğu gözlemlenmiştir. 1960 ile 1980 yılı arasındaki katılım oranında ortaya çıkan bu sonuçların bağlayıcıları; askeri iradenin sivil irade üzerinde yaratmış olduğu baskılar, siyasi kargaşalar ve seçim ortamına ilişkin güven eksiklidir. Türkiye'de 1960 - 1980 yılları arasında yapılan genel seçimlerde katılım oranı ortalaması \%71,2 olarak gerçekleşmiştir.

Türkiye'de hoşnutsuzluk endeksine ilişkin veriler Şekil 1.'de gösterilmiştir. Şekilde yıl aralığı 1960 ile 1980 yılları arasında olup, iki darbe arasındaki ekonomik veriler dikkate alınarak hesaplanmıştır. 1960 sonrasında kurulan Devlet Planlama Teşkilatı, 1961 Anayasası, 1971 yılında gerçekleşen askeri müdahale, 1973 yılında yaşanan Petrol Krizi, Kıbrıs harekâtı, sağ-sol kutuplaşmaları, iç karışıklıklar, Cumhurbaşkanı seçimlerinde askeri iradenin varlığı, sivil siyasete yapılan askeri girişimler ve son olarak 1980 darbesi, bu döneme damga vuran olayların başında gelmektedir. Bu yıllarda hesaplanan 
hoşnutsuzluk endeksi her seçim sonrasında artan oranlı olarak gerçekleştiği görülmekte ve dolayısıyla bu yıllarda politika yapıcıların ekonomi performanslarının sürekli olarak düştüğü ya da kötüleştiği sonucu ortaya çıkmaktadır.

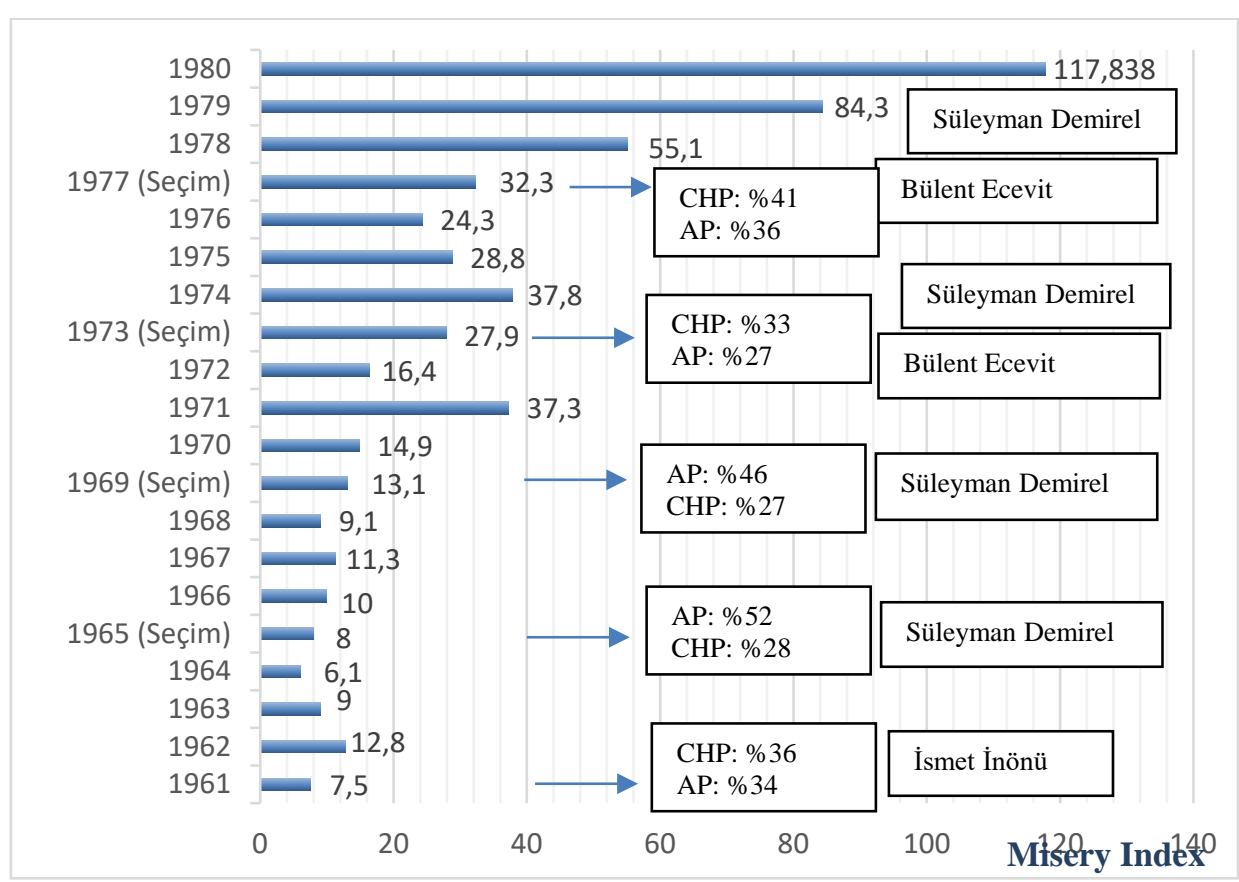

Şekil 1. Türkiye'de 1960 - 1980 Yılları Arasında Hoşnutsuzluk Endeksi (Kaynak: TUIK, Dünya Bankası, Kalkınma Bakanlığı ve TCMB)

Menderes hükümetini deviren 1960 darbecileri 1,5 y1lda 3 hükümet değiştirmiş ancak güçlü bir iktidar kurulamamıştır. 1961'de kurulan İnönü Başbakanlığındaki CHP-Adalet Partisi (AP) hükümeti, Türkiye'de ilk koalisyon olarak tarihe geçmiş ancak 7 ay sürmüştür. Özellikle hükümet kurmaktan yana güçlük çeken İnönü'nün bu dönemi ve hoşnutsuzluk endeksinde yaşanan yukarı yönlü ivme sonrasında 1965 seçimlerinde AP birinci parti olarak seçilmiş ve Süleyman Demirel dönemi başlamıştır. Süleyman Demirel döneminde hoşnutsuzluk endeksinde yükselmeler olsa da 1971 seçimlerinde tekrar seçildiği görülmektedir. Bu sonuç özellikle siyasi istikrar, güven ortamı ve Adalet Partisi'nin asker tarafindan devrilen Demokrat Parti misyonunu sahiplenmesi ile ilişkidir. İnönü hükümeti döneminde yaşanan siyasi istikrarsılılı seçmen tercihlerini etkilemiştir. Ancak yine de Türkiye'de bir grup seçmenin siyasi istikrardan ziyade rasyonel beklentilerinden kaynaklı (ekonomik göstergelerden dolayı) AP hükümetinden vazgeçtiği, seçim sonuçlarında da görülebilir. 1965 yılında AP'nin \%52 olan oy oranı, 1971 yılında \%46'ya düştüğü 
görülmektedir. Akabinde 1971 yılında yaşanan muhtıra ile Demirel hükümetinin düşürülmesi sonrası sırasıyla; Nihat Erim, Ferit Melen Başbakanlık yapmışlardır. Bu hususta 1960-1980 yılları arasında seçmen tercihleri ve partilerin aldığı oy oranları Tablo 2.'de gösterilmiştir.

Tablo 2. Seçmen Tercihleri ve Partilerin Aldığ 1 Oy Oranları “1960 - 1980”

\begin{tabular}{|c|c|c|}
\hline PARTÍLER & $\begin{array}{c}\text { TOPLAM OY } \\
\text { SAYISI }\end{array}$ & TOPLAM OY YÜZDESİ \\
\hline \multicolumn{3}{|c|}{1961 YILI GENEL SEÇİM SONUÇLARI } \\
\hline $\mathrm{CHP}$ & 3.724 .752 & 36,74 \\
\hline AP & 3.527 .435 & 34,79 \\
\hline CKMP & 1.415 .390 & 13,96 \\
\hline YTP & 1.391 .934 & 13,73 \\
\hline BAĞIMSIZ & 81.732 & 0,81 \\
\hline \multicolumn{3}{|c|}{1965 YILI GENEL SEÇİM SONUÇLARI } \\
\hline AP & 4.921 .235 & 52,87 \\
\hline $\mathrm{CHP}$ & 2.675 .785 & 28,75 \\
\hline MP & 582.704 & 6,26 \\
\hline YTP & 346.514 & 3,72 \\
\hline BAĞIMSIZ & 296.528 & 3,19 \\
\hline \multicolumn{3}{|c|}{1969 YILI GENEL SEÇİM SONUÇLARI } \\
\hline AP & 4.229 .945 & 46,55 \\
\hline $\mathrm{CHP}$ & 2.487 .163 & 27,37 \\
\hline GP & 598.013 & 6,58 \\
\hline BAĞIMSIZ & 511.097 & 5,62 \\
\hline $\mathrm{MP}$ & 293.849 & 3,23 \\
\hline MHP & 274.225 & 3,02 \\
\hline \multicolumn{3}{|c|}{1973 YILI GENEL SEÇİM SONUÇLARI } \\
\hline CHP & 3.570 .583 & 33,30 \\
\hline AP & 3.197 .897 & 29,82 \\
\hline $\mathrm{DP}$ & 1.275 .502 & 11,89 \\
\hline MSP & 1.265 .771 & 11,80 \\
\hline CGP & 564.343 & 5,26 \\
\hline MHP & 362.208 & 3,38 \\
\hline BAĞIMSIZ & 303.218 & 2,83 \\
\hline \multicolumn{3}{|c|}{1977 YILI GENEL SEÇİM SONUÇLARI } \\
\hline CHP & 6.136 .171 & 41,38 \\
\hline $\mathrm{AP}$ & 5.468 .202 & 36,88 \\
\hline MSP & 1.269 .918 & 8,56 \\
\hline MHP & 951.544 & 6,42 \\
\hline BAĞIMSIZ & 370.035 & 2,50 \\
\hline
\end{tabular}

Kaynak: Türkiye Büyük Millet Meclisi Kütüphane ve Arşiv Hizmetleri Başkanlığ1 
1973 seçimlerinde “Karaoğlan” lakaplı Bülent Ecevit'in yükselişi ile birlikte seçimlerde CHP \%33 oy oranı ile birinci parti çıkmayı başarmıştır. Aynı şekilde 1977 seçimlerinde de \%41 oy oranı ile birinci çıkan Ecevit, bu yıllarda hükümet kurma sorunları yaşamıştır. Ancak halk üzerinde yarattığı etki, seçildiği yıllarda yaşanan olumsuz ekonomik gelişmelere rağmen, tekrar birinci parti seçilmesine olanak tanımıştır. Öyle ki, Süleyman Demirel genel seçim sonuçlarında Karaoğlan'ın gerisinde kalmıştır. Bu yıllarda seçmenin daha çok sosyo-psikolojik bir davranış sergileyerek sandığa gittiği görülmektedir. Çünkü Türkiye'nin 19701980 yılları sağ-sol ideolojilerinin ağır bastığı yıllar olarak karşımıza çıkmaktadır.

Türkiye'nin 1960-1980 yılları arasında hem iç hem de dış faktörlerden kaynaklı yaşadığı olumsuz gelişmeler, seçmenin davranışını da etkilediği görülmektedir. Her ne kadar ekonomik gelişmeleri düşünen bir grup seçmenin varlığı görülse de bu yıllar daha çok seçmenin sosyo-psikolojik veya sosyolojik davrandığı yıllar olarak tabir edilebilir.

\section{0 - 2002 Yılları Arasında Hoşnutsuzluk Endeksi ve Seçim Sonuçları}

24 Ocak 1980 kararlarının ardından 12 Eylül Darbesi, Süleyman Demirel'in başında olduğu hükümeti görevden almış ve 1961 Anayasasını tamamen rafa kaldırarak, yeni bir anayasa getirmiştir. Bu darbe süreci, 1983 seçim yılına kadar sürmüştür. 1983 yılı ile birlikte seçilen Anavatan Partisi (ANAP), Turgut Özal liderliğinde Türkiye'de yeni bir ekonomi politikasını uygulamaya koymuştur. 1980 sonrası serbest piyasa ekonomisine geçen Türkiye'de 2002 yılına kadar sırasıyla; 1983, 1987, 1991, 1995 ve 1999 yıllarında genel seçim yapılmıştır. Askeri irade sonrasında sağlanan güven ortamının da etkisiyle bu seçim yıllarında katılım oranlarının arttığı da görülmektedir. 1983 ile 1999 yılları arasında gerçekleşen beş seçim sürecinde katılım oranı ortalaması \%88,3 seviyelerine ulaşmıştır. Bu rakam 1961-1977 arasında gerçekleşen rakamlara kıyasla oldukça yüksektir.

Tablo 3. Türkiye'de Seçim Y1lları ve Oy Kapasiteleri “1980-2002”

\begin{tabular}{|l|c|c|c|c|c|c|}
\hline $\begin{array}{l}\text { Seçim } \\
\text { Yılı }\end{array}$ & $\begin{array}{c}\text { Seçim } \\
\text { Tarihi }\end{array}$ & $\begin{array}{c}\text { Millet } \\
\text { Vekili } \\
\text { Sayısı }\end{array}$ & $\begin{array}{c}\text { Kullanılan } \\
\text { Oy }\end{array}$ & $\begin{array}{c}\text { Geçerli } \\
\text { Oy }\end{array}$ & $\begin{array}{c}\text { Geçersiz } \\
\text { Oy }\end{array}$ & $\begin{array}{c}\text { Katılım } \\
\text { Oranı }\end{array}$ \\
\hline $\mathbf{1 9 8 3}$ & $06 / 11 / 1983$ & 400 & 18.238 .362 & 17.351 .510 & 886.852 & $\% 92,3$ \\
\hline $\mathbf{1 9 8 7}$ & $29 / 11 / 1987$ & 450 & 24.603 .541 & 23.971 .629 & 631.912 & $\% 93,3$ \\
\hline $\mathbf{1 9 9 1}$ & $20 / 10 / 1991$ & 450 & 25.157 .089 & 24.416 .666 & 740.423 & $\% 83,92$ \\
\hline $\mathbf{1 9 9 5}$ & $24 / 12 / 1995$ & 550 & 29.101 .469 & 28.126 .993 & 974.476 & $\% 85,20$ \\
\hline $\mathbf{1 9 9 9}$ & $18 / 04 / 1999$ & 550 & 32.656 .070 & 31.184 .496 & 1.471 .574 & $\% 87.09$ \\
\hline
\end{tabular}

Kaynak: Türkiye Büyük Millet Meclisi Kütüphane ve Arşiv Hizmetleri Başkanlığı 
Tablo 3'te Türkiye'de 1983 yılından 1999 yılına kadar gerçekleşen seçim süreçleri, oy kullanım miktarları ve katılım oranları gösterilmiştir. Darbe öncesinde hem iç hem de diş dinamiklerde yaşanan olumsuz gelişmelerden dolayı kötü bir ekonomik performans sergileyen Türkiye ekonomisinin sahip olduğu hoşnutsuzluk endeksi rakamları 1980'de üç haneliye ulaşmıştır. Ancak darbe sürecinde düssen bu rakamlar, Özal döneminde de tekrar yükselişe geçtiği görülmektedir. Darbe süresince hoşnutsuzluk oranlarındaki düşme sebepleri arasında; tutuklama oranlarının yüksek olması, güven ortamının sağlanması ve dış ilişkiler ile ilgili yeni gelişmeler de bulunmaktadır.

12 Eylül 1980 askeri darbesi sonrası kapatılan siyasi partilerin yerine, 1983 seçimlerinde darbecilerin icazetiyle oluşturulan siyasi ortamda parlamentoya giren 3 parti; Milliyetçi Demokrasi Partisi, Halkçı Parti ve Anavatan Partisi'dir. 12 Eylül 1980 askeri darbesinin ardından ekonomiden sorumlu Başbakan yardımcılığına getirilen Turgut Özal seçimlerde birinci çıkmayı başarmıştır. Türkiye'de 1983-1999 yılları arasındaki hoşnutsuzluk endeksi, Şekil 2.'de gösterilmiştir.

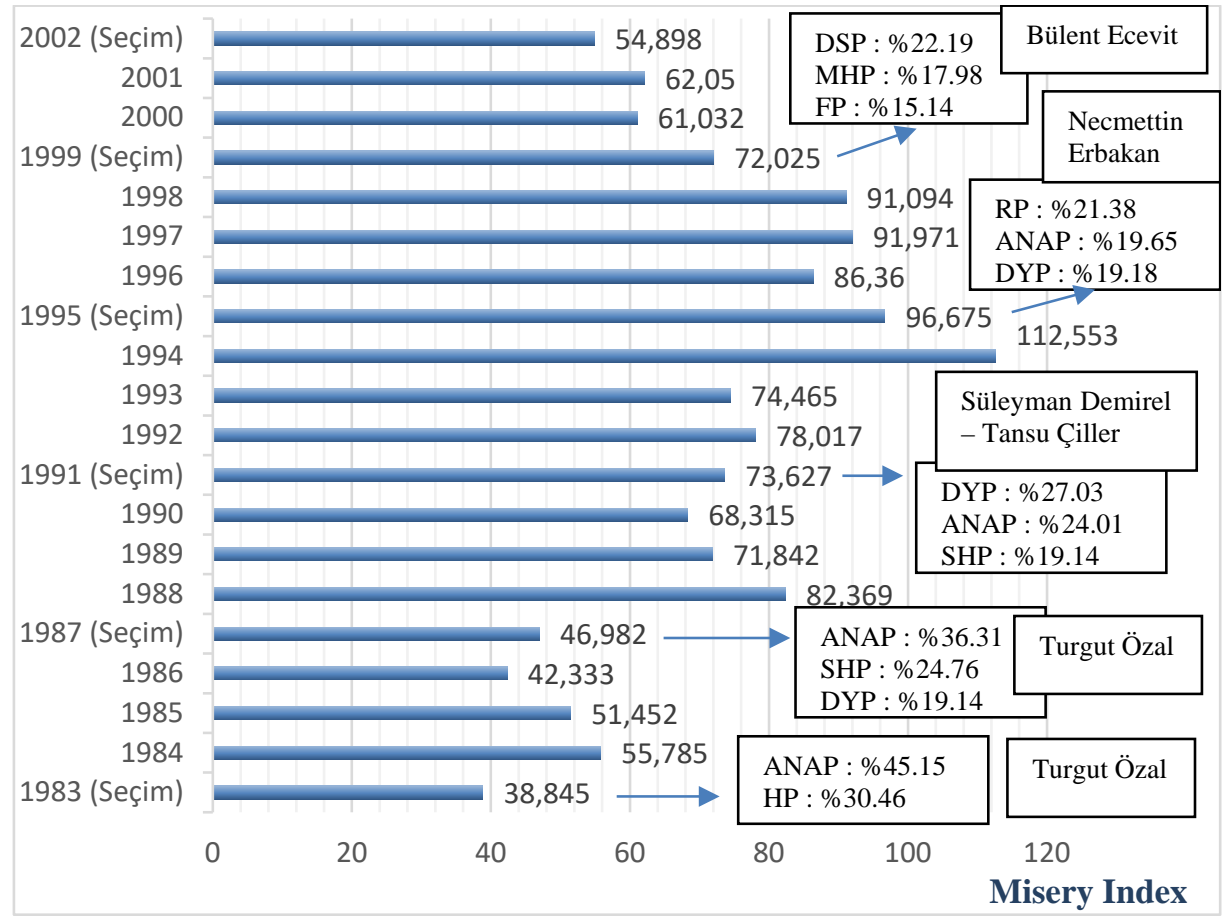

Şekil 2. Türkiye'de 1980 - 2002 Yı1ları Arasında Hoşnutsuzluk Endeksi (Kaynak: TUIKK, Dünya Bankası, Kalkınma Bakanlığı ve TCMB) 
1980 hükümeti düşüren darbe ile birlikte, hoşnutsuzluk endeksinde düşüş gerçekleşmiş ancak bu oranlar Özal döneminde tekrar yükselmeye başlamıştır. 1983 yılında \%45 ile seçilen Özal, 1987 yılında tekrar birinci seçilmiş olsa da oy oranları \%36'ya düşmüştür. Seçim sonrasında yine bu iktidar süresince enflasyon ve işsizlik oranlarındaki yüksek artışların meydana geldiği görülmektedir. Ancak bu dönemde Özal, Cumhurbaşkanı seçilmiş ve 1991 yılı seçimlerinde Mesut Yılmaz başkanlığında ANAP seçimlere katılmıştır.

1987 seçimi sonrasında yaşanan olumsuz ekonomik gelişmeler, 1990 körfez savaşı, terör olayları ve işçi ayaklanmaları, bu yıllarda ANAP hükümetinin performansını, diğer seçim yıllarına oranla daha fazla düşürmüş ve Türkiye ekonomisi bu gelişmelerden olumsuz etkilenmiştir. Yaşanan olumsuz gelişmeler, yüksek enflasyon ve işsizlik oranları sebebiyle 1991 yılında seçmenin tercihi Süleyman Demirel Başkanlığındaki Doğru Yol Partisi (DYP) olmuştur. Bu yılda seçmen, özellikle yaşanan olumsuz ekonomik gelişmelerin faturasını ANAP'a kesmiş ve yeni hükümeti görevlendirmiştir. ANAP'ın 1991'deki oy oranı \%26'lara düşmüştür.

1991 seçimleri, DYP-Sosyal Demokrat Halkçı Parti (SHP) koalisyonu kurulmuş ancak 1993 yılında Özal'ın vefatı ve Demirel'in Cumhurbaşkanı seçilmesi sonrası, Tansu Çiller hükümeti kurmakla görevlendirilmiştir. Ancak Tansu Çiller dönemi, Türkiye'de tarihsel olarak hoşnutsuzluk endeksinin en yüksek gerçekleştiği yıl olmuştur. Bu dönemde yaşanan ekonomik kriz 1995'te iktidarın sonunu getirmiştir. 1991 seçimlerinde olduğu gibi seçmen, bir kez daha yaşanan olumsuz gelişmeler dolayısıyla 1995 seçimlerinde Necmettin Erbakan liderliğinde Refah Partisi'ni (RP) birinci parti çıkarmıştır. Ancak bu dönemde koalisyon hükümetleri kurulmuş ve "post-modern" darbe girişimi ile Refah Partisi kapatılmıştır.

Türkiye'de 1999 yılı seçimleri, siyasi parti katılımının sayı olarak en fazla olduğu seçimler olarak tarihe geçmiştir. Bu seçimde \%10'luk seçim barajını aşan beş siyasi partiden DSP \%22, MHP \%17, Fazilet Partisi (FP) \%15, ANAP \%13 ve DYP \%12 ile meclise girmeyi başarırken, CHP \%10 barajını geçemeyerek Cumhuriyet tarihinde ilk defa meclis dışında kalmıştır. Bu yılda DSP, ANAP ve MHP'nin bir araya gelmesiyle 57. Hükümet kurulmuştur.

1999 yılı seçimlerinden sonra kurulan koalisyon hükümeti döneminde meydana gelen büyük Marmara depremi hem sosyal hem de ekonomik açıdan ülkeyi yıpratmış ve akabinde yaşanan 2000 ve 2001 ekonomik krizleri hükümete olan güveni zedelemiş̧ir. Yaşanan ekonomik sorunlar daha önceki seçimler olan 1991, 1995, 1999'da olduğu gibi 2002 seçimlerinde de sandığa yansımış ve seçmen, krizin sorumlusu olarak gördüğü koalisyon partileri cezalandırarak yeni bir partiyi birinci seçmiştir. Gerekli açıklamalar Tablo 4.'te gösterilmiştir. 
Tablo 4. Seçmen Tercihleri ve Partilerin Aldığ Oy Oranları “1980-2002”

\begin{tabular}{|c|c|c|}
\hline PARTÍLER & $\begin{array}{c}\text { TOPLAM OY } \\
\text { SAYISI }\end{array}$ & TOPLAM OY YÜZDESİ \\
\hline \multicolumn{3}{|c|}{1983 YILI GENEL SEÇİM SONUÇLARI } \\
\hline ANAP & 7.833 .148 & 45,14 \\
\hline HP & 5.285 .804 & 30,46 \\
\hline MDP & 4.036 .970 & 23,27 \\
\hline BAĞIMSIZ & 195.588 & 1,13 \\
\hline \multicolumn{3}{|c|}{1987 YILI GENEL SEÇİM SONUÇLARI } \\
\hline ANAP & 8.704 .335 & 36,31 \\
\hline SHP & 5.931 .000 & 24,74 \\
\hline DYP & 4.587 .062 & 19,14 \\
\hline DSP & 2.044 .576 & 8,53 \\
\hline $\mathrm{RP}$ & 1.717 .425 & 7,16 \\
\hline BAĞIMSIZ & 89.421 & 0,37 \\
\hline \multicolumn{3}{|c|}{1991 YILI GENEL SEÇIMM SONUÇLARI } \\
\hline DYP & 6.600 .726 & 27,03 \\
\hline ANAP & 5.862 .623 & 24,01 \\
\hline SHP & 5.066 .571 & 20,75 \\
\hline $\mathrm{RP}$ & 4.121 .355 & 16,88 \\
\hline DSP & 2.624 .301 & 10,75 \\
\hline SP & 108.369 & 0,44 \\
\hline BAĞIMSIZ & 32.721 & 0,13 \\
\hline \multicolumn{3}{|c|}{1995 YILI GENEL SEÇIMM SONUÇLARI } \\
\hline $\mathrm{RP}$ & 6.012 .450 & 21,38 \\
\hline ANAP & 5.527 .288 & 19,65 \\
\hline DYP & 5.396 .009 & 19,18 \\
\hline DSP & 4.118 .025 & 14,64 \\
\hline $\mathrm{CHP}$ & 3.011 .076 & 10,71 \\
\hline MHP & 2.301 .343 & 8,18 \\
\hline HADEP & 1.171 .623 & 4,17 \\
\hline BAĞIMSIZ & 133.895 & 0,48 \\
\hline \multicolumn{3}{|c|}{1999 YILI GENEL SEÇIM SONUCLARI } \\
\hline DSP & 6.919 .670 & 22,19 \\
\hline MHP & 5.606 .583 & 17,98 \\
\hline FP & 4.805 .381 & 15,41 \\
\hline ANAP & 4.122 .929 & 13,22 \\
\hline DYP & 3.745 .417 & 12,01 \\
\hline CHP & 2.716 .094 & 8,71 \\
\hline HADEP & 1.482 .196 & 4,75 \\
\hline BBP & 456.353 & 1,46 \\
\hline BAĞIMSIZ & 270.265 & 0,87 \\
\hline
\end{tabular}

Kaynak: Türkiye Büyük Millet Meclisi Kütüphane ve Arşiv Hizmetleri Başkanlığı 
Türkiye'de yaşanan olumsuz ekonomik gelişmeler 1983-1987 aralığ1 haricinde, 1987 yılı sonrasında hızla artmıştır. Bu tarihten itibaren seçmen, yaşanan her olumsuz ekonomik gelişmeyi iktidara bağlayarak her seçimde farklı bir partiyi birinci çıkarmıştır. 1991, 1995, 1999 ve 2002 seçim sonuçlarında sürekli olarak farklı partiler birinci çıkmıştır. Bu dönem, Türkiye'de koalisyon hükümetlerinin kurulduğu dönem olmuştur. Türkiye'deki siyasi istikrarsızlıklar, 1973’ten itibaren görüldüğü gibi, 1991 yılı sonrasında da ekonomik performansı olumsuz etkilemiştir. Bu dönemde seçmen davranışı, 1960-1980 yıllarından farklı olarak, daha çok ekonomik beklentiler çerçevesinde gerçekleştiği görülmektedir. Ancak yine de bir kesimin, özellikle Abdullah Öcalan'ın yakalanması sonrasın MHP'ye oy verdiği ve meclise girmesini sağladığı şeklinde çıkarım yapılabilir. Bu bağlamda 1977 ile 1999 yıllarındaki seçmen davranışının hemen hemen benzerlik gösterdiği ifade edilebilir.

\section{2 - 2019 Yılları Arasında Hoşnutsuzluk Endeksi ve Seçim Sonuçları}

1991 seçimleri sonrasında sürekli olarak yaşanan koalisyon dönemleri, terör faaliyetleri, ekonomik bunalımlar, komşu ülkelerdeki karışılıklar, darbe süreci ve en son olarak 2001 yılında meydana gelen kriz ile birlikte hali hazırda 1991 yılından beri her seçimde farklı bir partiyi birinci çıkaran seçmen, 2002'de de bu yönelimini sürdürmüştür. 2002 yılında Adalet ve Kalkınma Partisinin (AK Parti) başa gelmesiyle birlikte sırasıyla; 2002, 2007, 2011, 2015, 2015 (iki seçim) ve 2018 yıllarında genel seçim gerçekleştirilmiştir. Bu altı seçimde gerçekleşen katılım ortalaması \%84,4 olmuştur. Bu rakam, 1980-2002 yılları arasındaki seçime katılım ortalamasından daha düşük olarak gerçekleşmiştir. Gerekli açıklamalar Tablo 5.'te gösterilmektedir.

Tablo 5. Türkiye'de Seçim Yılları ve Oy Kapasiteleri “2002-2018”

\begin{tabular}{|l|l|c|c|l|l|l|}
\hline $\begin{array}{l}\text { Seçim } \\
\text { Yılı }\end{array}$ & $\begin{array}{c}\text { Seçim } \\
\text { Tarihi }\end{array}$ & $\begin{array}{c}\text { Millet } \\
\text { Vekili } \\
\text { Sayısı }\end{array}$ & $\begin{array}{c}\text { Kullanılan } \\
\text { Oy }\end{array}$ & Geçerli Oy & $\begin{array}{c}\text { Geçersiz } \\
\text { Oy }\end{array}$ & $\begin{array}{c}\text { Katılım } \\
\text { Oranı }\end{array}$ \\
\hline $\mathbf{2 0 0 2}$ & $3 / 11 / 2002$ & 550 & $32,753,388$ & $31,624,042$ & 1.129 .746 & $\% 79,10$ \\
\hline $\mathbf{2 0 0 7}$ & $22 / 07 / 2007$ & 550 & $36,056,293$ & $35,049,691$ & 1.006 .602 & $\% 84,25$ \\
\hline $\mathbf{2 0 1 1}$ & $12 / 06 / 2011$ & 550 & 43.914 .948 & 42.941 .763 & 1.000 .185 & $\% 83,16$ \\
\hline $\mathbf{2 0 1 5}$ & $07 / 06 / 2015$ & 550 & 46.491 .858 & 46.068 .291 & 423.567 & $\% 86,4$ \\
\hline $\mathbf{2 0 1 5}$ & $01 / 11 / 2015$ & 550 & 48.543 .394 & 47.858 .311 & 685.083 & $\% 87,7$ \\
\hline $\mathbf{2 0 1 8}$ & $24 / 06 / 2018$ & 600 & 51.183 .729 & 50.130 .419 & 1.053 .304 & $\% 86,2$ \\
\hline
\end{tabular}

Kaynak: Türkiye Büyük Millet Meclisi Kütüphane ve Arşiv Hizmetleri Başkanlığı

Türkiye'de 2002 yılı AK Parti'nin başa gelmesiyle birlikte koalisyon dönemleri kapanmış ve siyasi istikrar sağlanmıştır. Türkiye ekonomisinde, 1973 seçimlerden sonra ilk defa, hoşnutsuzluk endeksi oranı 20'nin altına inebilmiştir. 2002 yılı sonrasında uygulamaya konulan Güçlü Ekonomiye Geçiş Programı 
(GEGP), ekonominin olumsuz gidişatının düzelmesini sağlamış ve piyasaya olan güvenin tazelenmesini sağlamıştır. Aynı zamanda Tayyip Erdoğan liderliğinde AK Parti hükümeti, Avrupa Birliği (AB) sürecini ve dış ülkelerle olan ilişkilerini hızlandırarak, ülkenin dış ticaretinin büyümesini sağlamıştır. $\mathrm{Bu}$ dönemde yakalanan yüksek büyüme oranları ile birlikte hoşnutsuzluk endeksinde iyileşmeler gerçekleşmiştir. Bu bağlamda 2002 y1lı sonrasında gerçekleşen hoşnutsuzluk endeksi verileri Şekil 3.'te gösterilmiştir.

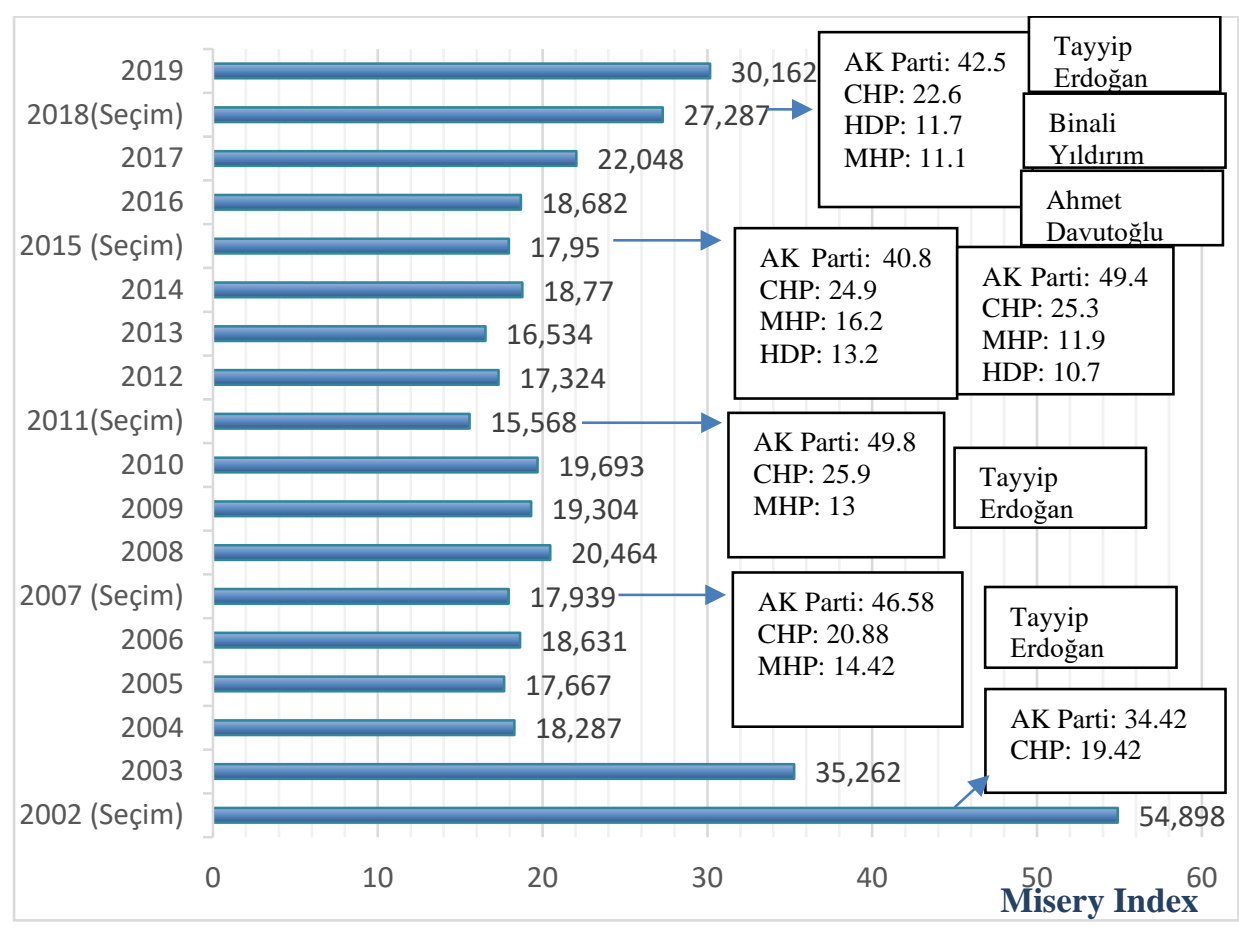

Şekil 3. Türkiye'de 2002 - 2019 Yı1ları Arasında Hoşnutsuzluk Endeksi (Kaynak: TUIKK, Dünya Bankası, Kalkınma Bakanlığı ve TCMB)

2002 yılında \%34 oy oranıyla birinci parti seçilen Ak Parti’nin ilk döneminde ekonomide yakaladığı başarılar sandığa da yansımış ve 2007 yılında $\% 46$ oy oranı ile tekrar iktidara seçilmiştir. Yine seçildiği ikinci döneminde hoşnutsuzluk endeksindeki iyileşmeler ve makroekonomik göstergelerdeki başarılar 2011 seçimlerine yansımış ve \%49 oy oranı ile tekrar birinci parti seçilmiştir. 2008 küresel krizi Türkiye ekonomisini olumsuz yönde etkilemiş olsa da yönetimce uygulanan politikalar vasıtası ile hızla toparlanmış ve 2011 yılında seçmen bu başarının sonucunu sandıkta göstermiştir. AK Parti hükümeti üç dönem art arda oylarını yükselterek Türkiye'de başa gelen tek parti olma özelliği göstermiştir. 
2002 ile 2019 yılına kadar AK Parti 8 defa hükümet kurmuş ve seçimlerde birinci parti olarak çıkmayı başarmıştır.

Türkiye için araştırmaya dahil edilen y1llar içerisinde genel olarak seçim dönemleri arasındaki ortalama hoşnutsuzluk endeksi, seçimlerde birinci gelen partilerin isimleri de belirtilerek, hesaplanmıştır. Bu husus Şekil 4.'te gösterilmiştir.

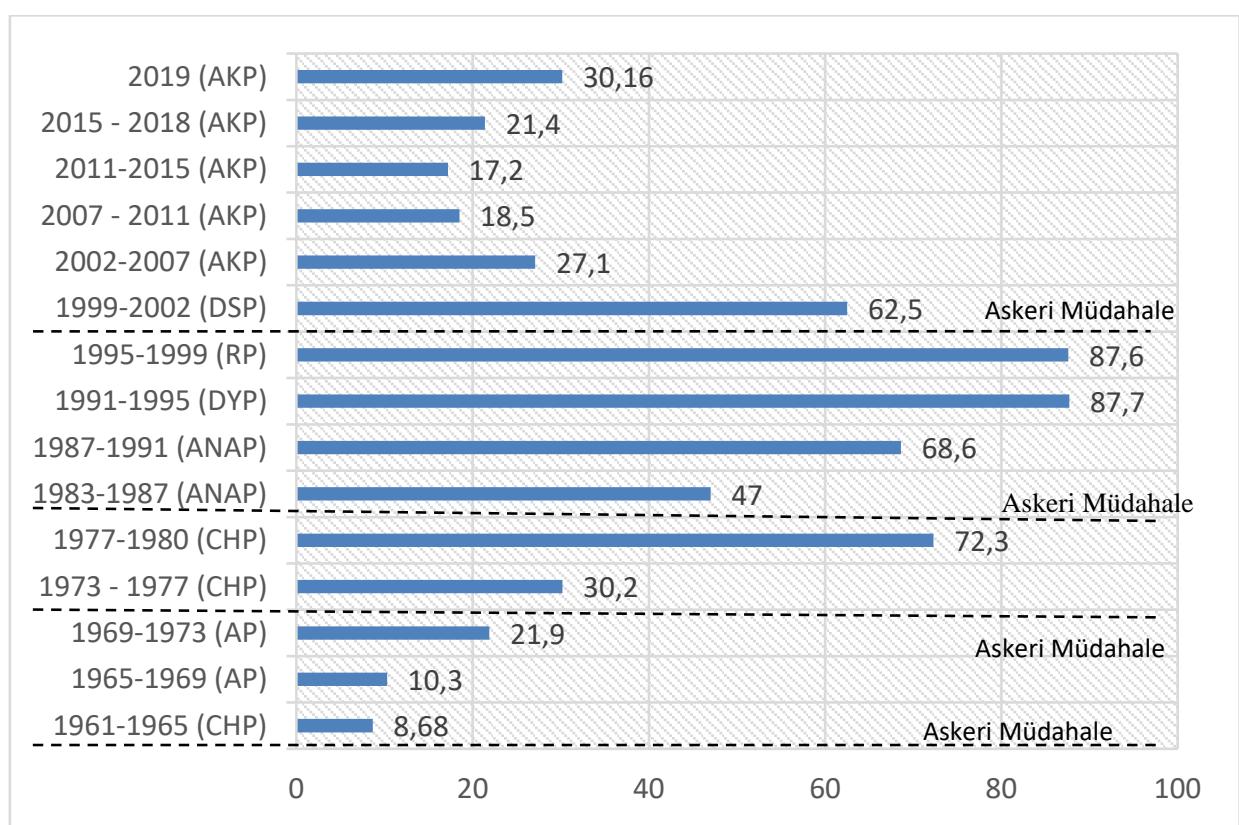

Not: Verilerin ayrıntılı açıklaması Ek-1'de sunulmuştur.

Şekil 4. Türkiye'de 1960 - 2019 Yı1ları Arasında Hoşnutsuzluk Endeksi (Kaynak: TUiK, Dünya Bankası, Kalkınma Bakanlı̆̆ı ve TCMB)

Türkiye'de 1960 darbesi sonrasında, 1980 yılına kadar hoşnutsuzluk endeksi sürekli olarak yükselmiştir. Bu dönemde yüksek işsizlik oranları ve yüksek enflasyon oranları ile karşılaşılmasına rağmen seçmenin sandıktaki davranışı daha çok ideolojik ve sosyo-psikolojik olarak gerçekleşmiştir.

1980 darbesi sonrası ANAP ile birlikte hoşnutsuzluk endeksinde yaşanan iyileşmeler sandığa yansımış ve 1987 yılında ANAP tekrar iktidara seçilmiştir. Ancak ANAP'ın seçildiği ikinci dönemde ekonomik performansın kötüleşmesi ve hoşnutsuzluk endeksinin yükselmesi sonucunda seçmen 1991 y1lında DYP'yi birinci parti olarak seçmiş ve ANAP'1 cezalandırmıştır. Ancak DYP döneminde yaşanan ekonomik kriz, seçmeni yeni bir partiye yöneltmiş ve 1995 seçimlerinde RP birinci parti olarak çıkmıştır. RP'nin darbe süreci ile düşürülmesi sonrasında 
1999 y1lında birinci parti olarak seçilen ve kurtarıcı olarak görülen Karaoğlan liderliğindeki DSP döneminde kurulan koalisyon hükümetinin hem ekonomik hem siyasi başarısızlığı sebebiyle 2002 yılı seçimlerinde ancak 2 parti, AK Parti ve CHP, meclise girebilmiştir. Dolayısıyla 2001 yılındaki ekonomik krizin sonuçları siyasi partiler için oldukça ağır olduğu söylenebilir. Devam eden yıllarda iktidara gelen AK Parti hükümetinin ekonomide yakaladığı başarılar seçmen tarafından ödüllendirilmiş ve AK Parti, ilk üç dönemde oylarını arttırarak seçimlerde birinci parti seçilmeyi başarmıştır. Ancak AK Parti iktidarı için geçerli olan bu husus, son yıllarda, tersine dönmeye başlamıştır. Bu sonucun temel bağlayıcıları ise iktidarın son dönemdeki ekonomi yönetimindeki başarısızlıklarıdır. $\mathrm{Bu}$ gelişmeler, yukarıda gösterilen Şekil 4.'te de görülebilmektedir. İlk üç dönem hoşnutsuzluk endeksinde yaşanan iyileşmeler, 2015 sonrası itibari ile olumsuz yönde seyretmeye başlamıştır. Diğer bir ifadeyle son yıllarda Türkiye'de enflasyon oranlarının tekrar çift hanelere ulaşması ve işsizlik oranlarında meydana gelen artışlar, hoşnutsuzluk endeksi rakamlarının tekrar yükselişe geçmesine neden olmuştur. Bu durum sebebiyle ilk üç dönemde sürekli olarak oylarını arttırarak birinci parti olarak seçilen AK Parti hükümetinin son seçimlerdeki oy oranlarının düştüğ̈̈ gözlemlenmektedir.

\section{SONUÇ VE DEĞERLENDİRME}

Hoşnutsuzluk endeksi, yönetimlerin ekonomik performanslarını göstermekle birlikte ülke ekonomileri açısından çok önemli bir ekonomik parametredir. $\mathrm{Bu}$ endeksin yükssek çıkmasının ekonomik yönden olumsuz sonuçları olduğu gibi sosyal ve toplumsal anlamda birçok sorunların yaşanmasına sebep olmaktadır.

Çalışma, Türkiye'de hoşnutsuzluk endeksinin seçmen üzerindeki rolünü ve yönetimlerin ekonomik performanslarını ortaya koymak amacıyla üç bölüme ayrılmış ve bu ayrımlar altında gerekli incelemeler yapılmıştır. Türkiye'de siyasi süreçlerin karmaşık bir yapıya sahip olması ve özellikle 1960 darbesi sonrasında sivil iradenin sürekli olarak askeri irade hegemonyası altında kalması sebebiyle yönetimlerin ekonomik performansları sürekli olarak düşüş göstermiştir. 1961 seçimlerinde CHP'nin birinci parti çıkmasının ardında ilk koalisyonun kurulması, henüz koalisyona alışık olmayan seçmen tarafından cezalandırılmış ve 1965 ve 1971 seçimlerinde AP birinci parti çıkmıştır. Ancak yine ekonomik performansta yönetimin yaşadığı başarısızlık ve 1971 yılında yaşanan askeri müdahale sonucunda tekrar CHP'nin birinci parti çıkması ve bu dönemde ortaya çıkan Petrol Krizi, hoşnutsuzluk endeksini yükseltmesine rağmen seçmen, Kıbrıs harekâtı ve lider vasfı sebebiyle tekrar CHP'de Karaoğlan'nı birinci parti olarak çıkarmıştır. Genel olarak 1960-1980 yılları arasında ekonomik göstergelerden daha çok, siyasi ve sosyal hareketin seçmen üzerinde etkili olduğu görülmektedir. $\mathrm{Bu}$ durumun temel sonuçlarından biri, bu dönemde ideolojilerin daha ağır bastığı 
ve halkın bu ideolojilere yöneldiği, sandığa da bu düşünceyi yansıtmasından ileri gelmektedir.

İktidar partilerin ekonomik açıdan başarısızlığı, seçmen tarafından cezalandırılmış olsa da bu durum 1960 - 1980 yılları arasında \%5 ila \%10 arasında geçerlilik kazanmıştır. 1980 darbesi sonrası tekrar şekillenen siyaset düzleminde iktidara getirilen ANAP hükümeti, 1987 yılı seçimlerine kadar ekonomide olumlu atılımlar gerçekleştirmiş ve halk tarafından tekrar 1987 yılında birinci parti olarak seçilmiştir. Ancak 1987 yılı sonrasında tekrar kötüleşen ekonomi, akabinde seçmen tarafından cezalandırılarak 1991 yılında DYP seçimleri kazanmıştır. Ancak DYP'nin de ekonomik performansındaki başarısızlığ 1 , tekrar seçmen tarafindan cezalandırılarak, 1995'te RP'yi birinci parti olarak çıkarmış ancak darbe süreci ile hükümet düşürülmüş̧ür. 1999'da Öcalan'ın yakalanması ve ekonomiye çare olması amacıyla Ecevit'e tekrar şans tanıyan seçmen, DSP'yi birinci parti çıkarmıştır. 1980 - 2002 yılları arasındaki dönem, genel olarak (ANAP 1983-1987 hariç), hükümetlerin yönetimde başarısız olduğu ve halk tarafından bu başarısızlığın cezasının da verildiği bir dönem olmuştur. Dolayısıyla bu dönem, 1960-1980 yıllarından farklı olarak, artık serbest piyasa ekonomisine geçen Türkiye halkının, ekonomik çıkarlarını daha fazla önemsediğinin göstergesi olmuştur.

2002 yılında, krizin halk üzerindeki maliyetleri sandığa da yansımış ve bu yılda sadece AK Parti ve CHP meclise girebilmiştir. 2002 y1lı sonrasında sırasıyla; 2002, 2007 ve 2011 yıllarında hoşnutsuzluk endeksinde sürekli düşüşler ve yönetimin ekonomik performansındaki başarıları seçmen tarafindan ödüllendirilerek, üç dönem boyunca AK Parti hükümeti oy oranını arttırarak tek başına iktidara seçilmiştir. Ancak 2011 yılı sonrasında tekrar yükselişe geçen enflasyon ve işsizlik rakamları, 2015 Haziran seçimlerinde AK Parti'nin oy oranını düşürmüş olsa da 2015 Kasım seçiminde bu oranlar tekrar yükselerek (siyasi istikrarı isteyen seçmen ile) tekrar tek başına iktidara gelmeyi başarmıştır.

1960 - 1980 yılları arasında seçmenlerin seçime katılım oranının düşüklüğü Türk toplumunun siyasete ve siyasal partilere olan güvensizliğinin bir sonucu olarak karşımıza çıkmaktadır. Fakat her şeye rağmen seçmen var olan sorunlarını çözmek için siyasi partilerin ana omurgasını oluşturduğu demokrasiyi bir araç olarak kullanmaktadır. 1980 sonrası serbest piyasa ekonomisine geçen Türkiye toplumu, önceki döneme nazaran, ekonomik çıkarlarını ön plana getirerek sandığa gitmiş ve bu konuda başarılı olabilecek seviyede uygun gördügü partiyi seçmiştir. Ancak 1991 ve 2002 yıllar arasında sürekli olarak yönetimlerin başarısızlı̆̆ 1 , seçmenin farklı partilere yönelmesine sebep olmuştur. Ayrıca Türkiye'de 2002 yılı sonrasında yakalanan ekonomik başarılar, seçmen tarafından ödüllendirilerek AK Parti iktidarının oy oranlarını sürekli olarak arttırmıştır. Ancak son yıllarda ekonomide yaşanan kötü gidişat ve siyasi olarak 
kutuplaşmaların varlığı; seçmenin siyasete olan ilgisinin giderek azaltmaktadır. Böylece katılım oranları düşmekte ve ekonomideki kötü gidişat AK Parti iktidarının oy oranlarını düşürmektedir.

Türkiye'de seçmen; işsizlik, enflasyon ve ekonomik büyüme gibi göstergelere, özellikle 1980 sonrası itibari ile önem verdiği görülmektedir. Bu hususta; milli gelirde gerçekleşen artışlar iktidarın oylarını pozitif yönde etkilerken; enflasyon ve işsizlik negatif yönde etkilemiştir. Yönetimlerin ekonomik başarıları, iktidar sürelerini ve oy oranlarını belirlemektedir. $\mathrm{Bu}$ sebeple yönetimler ve politika yapıcıları, hoşnutsuzluk endeksinin düzeltilmesi ve aşağıya çekilmesine ilişkin çalışmalar yapması gerekmektedir. Bu çalışmalar iktidarın oy kapasitesini ve halk tarafından verilen desteğin arttırılabilmesi adına önemlilik arz etmektedir.

\section{KAYNAKÇA}

Adaman, F., Çarkoğlu, A. ve Şenatalar, B. (2001). İ̧̧ dünyası gözünden Türkiye'de yolsuzluğun nedenleri ve önlenmesine ilişkin öneriler. TESEV Yayınları.

Adrangi, B. and Joseph M. J. (2019). Does the misery index influence a U.S. President's political re-election prospects?. Journal of Risk and Financial Management, 12 (22), 1-11.

Akgün, B. (2000). Türkiye'de seçmen davranışı: Partizan tutumlar, ideoloji ve ekonomik faktörlerin oy vermeye etkisi. Selçuk Üniversitesi Sosyal Bilimler M.Y.O Dergisi, 4, 75-92

Barro, R. J. (1999). Reagan vs. Clinton: Who's the economic champ? Business Week. Economic Viewpoint, 22.

Blanchflower, D. G. (2007). Is unemployment more costly than inflation?”. NBER Working Paper, 13505

Choi, S. W., James, P., Li, Y. and Olson, E. (2016). Presidential approval and macroeconomic conditions: Evidence from a nonlinear model. Applied Economics 48, 4558-4572.

Çaha, Ö. (2008). Türkiye'de seçmen davranışı ve siyasi partiler. Orion Kitabevi.

Çakır, H. ve Biçer, A. (2014). Türkiye'de yerel seçimlerinde seçmen tercihlerini etkileyen kriterler: 30 Mart yerel seçimleri Kayseri örneği. Erciyes İletişim Dergisi, 4 (1), 98-112. 
Çarkoğlu, A. ve Toprak, B. (2000). Türkiye'de din toplum ve siyaset. TESEV Yayınları

Çinko, L. (2006). Seçmen davranışları ile ekonomik performans arasındaki ilişkilerin teorik temelleri ve Türkiye üzerine genel bir değerlendirme. Ankara Üniversitesi SBF Dergisi, 61-1.

Dickerson, B. (2016). Economic perceptions, presidential approval, and causality: The moderating role of the economic context. American Politics Research, 44, 1037-1065.

Dünya Bankası (2019). Türkiye'de GSYIH büyüme oranları (\%). https://data.worldbank.org/indicator/NY.GDP.MKTP.KD.ZG?locations= TR

Ercins, G. (2007). Türkiye'de sosyo-ekonomik faktörlere bağlı olarak değişen seçmen davranışı. Íktisadi ve İdari Bilimler Dergisi, 8 (2), 25-40.

Esmer, Y. (2002). At the ballot box: Determinants of voting behavior in Turkey. Lynne Rienner Publishers

Fair, R. C. (1982). The effect of economic events on votes for president: 1980 results. Review of Economics and Statistics, 10, 322-25.

Fair, R. C. (1978). The effects of economic events on votes for president. Review of Economics and Statistics, 60, 159-73.

Fair, R. C. (1988). The effect of economic events on votes for president: 1984 Update. Political Behavior, 10, 168-79.

Grabia, T. (2011). The Okun misery index in european union countries from 2000 to 2009. Comparative Economics Research, 14, 97-115.

Gül, H., Cansever, N. ve Turhan, M. (2015). 2011 genel ve 2014 yerel seçimlerinde Isparta'da seçmen davranışı analizi. Toplum ve Demokrasi Dergisi, 9 (19), 225-241.

Hanke, S. H. (2009). The misery index: A reality check for the US and Jamaica, Jamaica Observer, September, 6

Herman, E. (2010). Inflation and unemployment in the Romanian economy. Annals of The University of Petroşani, Economics, 10 (2), 157-170.

Kalaycioglu, E. (1999). The shaping of party preferences in Turkey: Coping with the post-cold war era. New Perspectives on Turkey, 20, 47-76. 
Kalkınma Bakanlığı (2015). Ekonomik ve sosyal göstergeler. https://www.sbb.gov.tr/wpcontent/uploads/2018/11/Ekonomik_ve_Sosyal_Gostergeler_1950_2014. pdf

Kenski, H. (1977). Inflation and presidential popularity. The Public Opinion Quarterly, 41, 86-90.

Kenski, H. (1980). Economic perception and presidential popularity: A comment. The Journal of Politics, 42, 68-75.

Layton, A. (1992). An estimated Australian macroeconomic misery index. Economic Record 68, 118-24.

Lechman, E. (2009). Okun's misery index as an alternative poverty assessment tool. recent estimations for European countries. MPRA Paper, 37493.

Moesen, W. and Cherchye, L. (1998). The macroeconomic performance of nations measurement and perception. Centre of Economic Studies Catholic University of Leuven Discussion Paper Series. DPS98.22. August.

Mueller, J. E. (1970). Presidential popularity from Truman to Johnson. American Political Science Review, 64, 18-34.

Mueller, J. E. (1973). War, presidents, and public opinion. Wiley Publishing

Norpoth, H. (1984). Economics, politics, and the cycle of presidential popularity. Political Behavior, 6, 253-73.

Okun, A.M. (1970). The political economy of prosperity. The Brookings Institution

Özer, İ. ve Meder, M. (2008). Siyasal katılma ve seçmen davranışı. Ege Yayınları.

Rogoff, K. and Sibert, A. (1988) Elections and macroeconomic policy cycles. Review of Economic Studies, 55, 1-16.

Sencer, M. (1974). Türkiye'de sınıfsal yapı ve seçmen davranışları. May Yayınları.

Türkiye Büyük Millet Meclisi Kütüphane ve Arşiv Hizmetleri Başkanlığ (2019). Türkiye Cumhuriyeti milletvekili genel seçimleri. https://www5.tbmm.gov.tr//develop/owa/secim_sorgu.genel_secimler 
Türkiye İstatistik Kurumu (2019). TÜFE, istatistik veri portall. https://data.tuik.gov.tr/Kategori/GetKategori?p=Enflasyon-ve-Fiyat-106

Welsch, H. (2007). Macroeconomics and life satisfaction: Revisiting the misery index. Journal of Applied Economics, 10 (2), 237-51. 


\section{EKLER}

Ek-1. Ele Alınan Yıllarda Türkiye'de Hesaplanan Hoşnutsuzluk Endeksi

\begin{tabular}{|c|c|c|c|c|c|c|c|}
\hline YIL & $\begin{array}{c}\text { ENFLASYON } \\
\text { ORANI (\%) }\end{array}$ & $\begin{array}{c}\text { İŞSİZLIK } \\
\text { ORANI } \\
(\%)\end{array}$ & $\begin{array}{c}\text { ELDE } \\
\text { EDİLEN } \\
\text { ENDEKS }\end{array}$ & YIL & $\begin{array}{c}\text { ENFLASYON } \\
\text { ORANI (\%) }\end{array}$ & $\begin{array}{c}\text { İŞSİZLİK } \\
\text { ORANI } \\
(\%)\end{array}$ & \\
\hline 1961 & 4.1 & 3.4 & 7.5 & 1991 & 65.967 & 7.66 & 73.627 \\
\hline 1962 & 9.5 & 3.3 & 12.8 & 1992 & 70.073 & 7.944 & 78.017 \\
\hline 1963 & 5.7 & 3.3 & 9 & 1993 & 66.097 & 8.368 & 74.465 \\
\hline 1964 & 2.6 & 3.5 & 6.1 & 1994 & 104.54 & 8.013 & 112.55 \\
\hline 1965 & 4.3 & 3.7 & 8 & 1995 & 89.566 & 7.109 & 96.675 \\
\hline 1966 & 6.4 & 3.6 & 10 & 1996 & 80.236 & 6.124 & 86.36 \\
\hline 1967 & 6.5 & 4.8 & 11.3 & 1997 & 85.653 & 6.318 & 91.971 \\
\hline 1968 & 3.9 & 5.2 & 9.1 & 1998 & 84.721 & 6.373 & 91.094 \\
\hline 1969 & 7.2 & 5.9 & 13.1 & 1999 & 64.87 & 7.155 & 72.025 \\
\hline 1970 & 8.5 & 6.4 & 14.9 & 2000 & 55.035 & 5.997 & 61.032 \\
\hline 1971 & 30.5 & 6.8 & 37.3 & 2001 & 54.246 & 7.804 & 62.05 \\
\hline 1972 & 10.2 & 6.2 & 16.4 & 2002 & 45.134 & 9.764 & 54.898 \\
\hline 1973 & 21.1 & 6.8 & 27.9 & 2003 & 25.337 & 9.925 & 35.262 \\
\hline 1974 & 30.5 & 7.3 & 37.8 & 2004 & 8.599 & 9.688 & 18.287 \\
\hline 1975 & 21.2 & 7.6 & 28.8 & 2005 & 8.179 & 9.488 & 17.667 \\
\hline 1976 & 15.3 & 9 & 24.3 & 2006 & 9.597 & 9.034 & 18.631 \\
\hline 1977 & 24 & 8.3 & 32.3 & 2007 & 8.756 & 9.183 & 17.939 \\
\hline 1978 & 46.7 & 8.4 & 55.1 & 2008 & 10.444 & 10.02 & 20.464 \\
\hline 1979 & 75.6 & 8.7 & 84.3 & 2009 & 6.251 & 13.053 & 19.304 \\
\hline 1980 & 110.638 & 7.2 & 117.838 & 2010 & 8.566 & 11.127 & 19.693 \\
\hline 1981 & 36.364 & 7.2 & 43.564 & 2011 & 6.472 & 9.096 & 15.568 \\
\hline 1982 & 31.111 & 7.6 & 38.711 & 2012 & 8.892 & 8.432 & 17.324 \\
\hline 1983 & 31.335 & 7.51 & 38.845 & 2013 & 7.493 & 9.041 & 16.534 \\
\hline 1984 & 48.378 & 7.407 & 55.785 & 2014 & 8.855 & 9.915 & 18.77 \\
\hline 1985 & 44.506 & 6.946 & 51.452 & 2015 & 7.671 & 10.279 & 17.95 \\
\hline 1986 & 34.617 & 7.716 & 42.333 & 2016 & 7.775 & 10.907 & 18.682 \\
\hline 1987 & 38.851 & 8.131 & 46.982 & 2017 & 11.144 & 10.904 & 22.048 \\
\hline 1988 & 73.668 & 8.701 & 82.369 & 2018 & 16.332 & 10.955 & 27.287 \\
\hline 1989 & 63.267 & 8.575 & 71.842 & 2019 & 17.459 & 12.703 & 30.162 \\
\hline 1990 & 60.317 & 7.998 & 68.315 & 2020 & 14.6 & 13.2 & 27.8 \\
\hline
\end{tabular}

